\title{
The Nexus between Female Child Trafficking and Pakhtun Culture in Peshawar
}

\author{
* Dr. Syed Rashid Ali, Associate Professor \\ ** Dr. Hussain Ali, Lecturer \\ *** Dr. Ahmad Ali, Assistant Professor
}

\begin{abstract}
The present study aims to investigate the factors and forms of female child trafficking in Pakhtun society from the perspective of opinion of leaders and experts. It enlists some of the cultural factors and forms of marriages, which provide critical space for the practice of trafficking even though it goes unnoticed in Pakhtun society. For this purpose, data were collected from 392 respondents, consisting of 116 university teachers, 103 journalists and 173 legal practitioners from Peshawar. Data were collected through a questionnaire. Cronbach's Alpha test was used to know about the reliability of the tool which was 0.7. Analyses were carried out with the help of suitable statistical tests of Chi square, and gamma. Simple frequency distribution, bi and multivariate level of analyses were carried out. The study found that all the study indicators of Pakhtun culture are responsible for providing breeding ground for female child trafficking. Bride price, excessive dowry compensation marriage (locally known as Swara marriage), and forced marriage are the main factors and forms responsible for female child trafficking in the study area. Results at bivariate and multivariate confirm each other where gender has no critical role in the resulted association between the two variables.
\end{abstract}

Keywords: Culture, Forms, Factors, Female Child Trafficking, Pakhtun Society, Association.

\section{Introduction}

The socio-cultural structure of Pukhtuns is dominated by male, and female have little access to explain and/or define their position. They are forced to function in accordance with the patriarchal structure although in developed countries, they have challenged their position (Papps, 1993). Nevertheless, in traditional societies like that of Pakhtuns, female have no option but to follow the structural demands considered normal by the society.

\footnotetext{
* Department of Sociology, Abdul Wali Khan University Mardan. Email: syedrashid@awkum.edu.pk ** Department of Sociology, Abdul Wali Khan University Mardan. Email: hussainali@awkum.edu.pk *** Department of Sociology, Abdul Wali Khan University Mardan. Email: ahmadalia@awkum.edu.pk
} 
Pakhtunwali defines the status of female strictly and she is exceptionally expected to be an abiding member. Any deviation by her is considered dishonor and shame for her and for her family. She has to undergo an exemplary treatment by the society in general and by kinship members in particular. Even the birth of a girl is usually unwelcomed in Pakhtun society. Similarly, she is considered property by husband after marriage. She is for house or grave as depicted in a Pakhto proverb "khaza ya d kor daya d gor" (Shah, 2007; Ahmad, 1986).

Alternatively, Pakhtun society bestows the highest status to female when she is in the role of mother $(M O R)$, but she is annihilated if she is labeled with tor (Ahmad, 1986). A blamed (labeled with tor) female is provided with any social space for reintegration in Pakhtun society. Such phenomenal perception and practices show the extreme form of framework or code of conduct designed in Pakhtun society with specific reference to female. Pakhtun society is considered a man's world. The code of Pashtunwali is dominated by men. However, surprisingly, it is supported by women (Ahmad, 1986). Keeping in view the above, the present study aims to analyze if Pakhtun culture and traditions with specific reference to female is providing space to human trafficking. This study also tries to explain the influence of gender on the perception of respondents with reference to the factors associated with female child trafficking. Before embarking on the factors and forms of child trafficking reported by scholars from different part of the world, the definitions and status of Pakistan is described as under:

The UN ${ }^{1}$ Convention against Transnational Organized Crime (2000) defined child trafficking (CT) as,

"the recruitment, transportation, transfer, harboring or receipt of persons, by means of threat or use of force or other forms of coercion, abduction, fraud, deception, of abuse of power, giving or receiving of payments or benefits to achieve the consent of a person having control over another person for the purpose of exploitation; exploitation shall include, at a minimum, prostitutions, other forms of sexual exploitation, forced labor or services, slavery or practices similar to slavery, servitude or the removal of organs".

${ }^{1}$ UN stands for United Nations 


\section{Literature Review}

The relevant literature is reviewed in this section however, the status of the issue globally and thereafter within Pakistan is provided before the major part of this section i.e., Pakhtun culture and child trafficking.

\section{Global Status}

No exact data is available about the actual status of female child trafficked victims. However, USA tries to convince countries for the data base and enactment of laws to deal these cases. There is no consensus on the definition and or forms of human trafficking among the international community. This also makes it difficult to have data on the issue. It is estimated that about 0.6 to 0.8 million people become victim of transnational human trafficking each year. What is the status on internal trafficking, seems impossible to be presented yet (IPEC$\mathrm{TBP}^{2}$, 2007).

\section{Pakistan Status}

Reliable data on child trafficking of any form are missing in Pakistan (Ali, 2013). Nevertheless, few scholars and organizations wrote about some cases of human trafficking e.g. Tumlin (2000) wrote about camel jockeys; Kane (1998) mentioned business of prostitution in Pakistan; TICSA (2002) wrote about bonded labor; Iijima (1998) CATW (2003), Ahmed (1997). In accordance with ILO (2002), Pakistan not only sends but receives victims of human trafficking. Even for some, Pakistan becomes root to move to other countries. Within Pakistan, some source places are identified in all the provinces. In Sindh, Noushera Feroz Abad and Jacobabad, in Pakhtunkhwa, Swat, Peshawar and Chitral, in Punjab, Gujarat and Sialkot are the source places for human trafficking (see for example Azam, 2009; ILO, 2002; NET, 2008). Pakistan passes law only on international human trafficking, while internal trafficking is covered under various provisions of different laws. Nevertheless, few studies reported trafficking cases from different parts of the country.

\section{Pakhtun Culture and Child Trafficking}

As claimed in the introduction, Pakhtun culture is providing breeding ground to traffickers for exploitation of the female. Honor is one of the critical components of the Pakhtun culture, which is dominantly associated and restricted to female. She is expected to be protecting her honor being counterpart and representative of the honor of the whole family. Any deviation, whether intentional or unintentional, willful or under deceit and fraud, from the expected norms of honor would lead to her annihilation. This culturally backed sanction of honor

\footnotetext{
${ }^{2}$ IPEC TBP stands for International Program on the Elimination of Child Labour-Time Bound Program
} 
killing produces fear in female where she keeps herself away from the home and resultantly remains under the mercy of exploiters. She keeps her lips tight and accepts exploitation rather than to become prey to the cultural norms of honor killing (Azam, 2009; Ali, 2013; Saewyc \& Edinburgh, 2010).

Another factor reported by research studies is non-reporting of the issue. Hiding such victimization from reporting due to fear of shame exposed families to re-victimization (Afonja, 2001). Sensitivity of honor and confidentiality become highly responsible for not giving data to the researchers (see Muhammad, 2005). In most of the cases, parents could not share the matter of sexual exploitation of their kids and keep one away from reporting to the police. Non-reporting of such sensitive issues due to shame and honor further motivates traffickers (Child Rights International Network \{CRIN\}, 2005). Girls in Pakhtun community like Afghanistan are prone to abuse because of the stigma attached culturally to the females in sexual cases (IOM, 2004). The social space contracted for abused girls in the rigid cultures helps the traffickers to entrap these girls (Ali, Abdullah, Khan, \& Karim, 2014; Saewyc \& Edinburgh, 2010).

The cultural definition of gender where male is considered and rewarded with superior social status and female with inferior status is known as gender inequality (Encyclo, 2007). Such unequal situation provides breeding ground for the exploitation of female. Where such gender discrimination prevails unnoticed, the life of the female remains at high risk to various exploitative practices including sex trafficking (Ali, Abdullah, Khan, \& Karim, 2014; Schauer \& Wheaton, 2006; Morash, 2006). The argument is confirmed in the study of Trujillo (2004), where he concludes that lower status of female in the nine Latin American countries make them prone to human trafficking. Another study also confirms the relation of gender discrimination aspect of culture and child trafficking, which reports that those cultures, where boys are more valuable than girls like Asian cultures, provide easy pitch to the traffickers to play their dirty game. Due to poverty, illiteracy and unawareness, girls in such cultures are known to be exchangeable items that can be used for trade, sale, or bargaining (Chung, 2006; Jeffreys, 2009; Morash, 2006; Raymond et al., 2010; Ali, 2013).

Some other studies further explored the end product of culturally approved gender discrimination in the practice of arrange marriages by poor families where they receive handsome amount in shape of dowry. Mostly, such marriages result into forced prostitution and/or selling to brokers which are reported in various South Asian countries (e.g., see ILO, 2006; Sinha, 2005). 
In some cases, the parents' disowning of sexually abused girl, provides space to the traffickers in Pakistan (NET, 2008). This practice is also experienced by Burmese female while facing the culture of stigmatization or social boycott of sexually abused girls (Chung, 2006). In the traditional society, rigid culture and the hard line of "right and wrong" and rigid social sanctions and taboos against premarital sexually abused girls have minimized opportunity for them (Tumlin, 2000). Such a girl has no alternative except to present herself as item for some give and take.

The normative structure of purchased and forced marriages produced a market type situation, and mafia easily runs their businesses (Azam, 2009; Shah, 2004; Muhammad, 2005). These girls become commodities for such business persons/criminal syndicates due to the exploitative aspect of culture (Chung, 2006; Mirza, 2010; ILO, 2006; Wolthuiss \& Black, 2001; IOM, 2004; Sinha, 2005; US TIP, 2008; NET, 2008). The customary practice of bride price in Pakhtun society not only provides breeding grounds for human trafficking, rather, it is itself a form of trafficking. Another exploitative but culturally approved practice of swara marriage is also a form of human trafficking prevailing in Pakhtun society (NET, 2008; Shah, 2004; Muhammad, 2005; Mirza, 2010).

The study is guided with the routine activities theory of Cohen and Felson (1979). This theory by explaining the interplay of the three variables i.e., suitable target, absence of capable guardian and motivated offender, predicts the commission of crime.

\section{Materials and Methods}

The study is conducted in district Peshawar, Khyber Pakhtunkhwa. The study is quantitative in nature where data is collected through closed ended questionnaire with options agree, disagree and not sure in the form of a Likert scale. The questionnaire is constructed with the help of literature and researchers' observations. The same is checked for face and content validity through experts of the field, particularly from social sector. Similarly, for its internal consistency, Cronbach's Alpha test is carried out where it was 0.7. The data is collected from 392 respondents out of the total population of 453. They are Academicians, Journalists, and Lawyers. The 392 sample size was decided through a formula of Casley and Kumar (1989). After selecting the number of people they were distributed proportionately and respondents were selected randomly. Data is then analyzed while using SPSS for simple frequency distribution, bivariate and multivariate level. For bivariate and multivariate analyses, the variables are indexed in line with Nachmias and Nachmias (1992). Multivariate analyses were carried out by controlling gender as background variable. 


\section{Results and Discussions}

This section describes and explains the results which are divided into univariate, bivariate, and multivariate analyses. In univariate analysis the results of independent and dependent variables are described in the first two tables with all the items/statements. The third and fourth tables contain bivariate and multivariate results, where independent and dependent variables are indexed and used. These results are explained and compared with the referred literature for drawing conclusion about the results.

\section{Factors of Female Child Trafficking}

As specified in Table 1, almost 52\% of the respondents agree that fear among the female prevails in Pakhtun society due to cultural approval of honor killing. Similarly, about 67\% respondents agree that non-reporting of cases in Pakhtun society is due to fear of shame which may reduce the social status of families which they raised in years and years. Majority of the respondents (48.7\%) agree with the statement that gender inequality exists in Pakhtun society. A considerable number of respondents also disagree with the above statement as well. Likewise, $52 \%$ of the respondents agree with the statement that Pakhtun practices the custom of excessive dowry in their society. About 55\% agree that Pakhtun disowns sexually abused females. About the prevalence of cultural approval of forced child marriage, purchase marriage and Swara marriage, majority of the respondents i.e., $60.5 \%, 65.6 \%$ and $49.2 \%$ respectively agree.

\begin{tabular}{|l|l|l|l|l|}
\hline \multicolumn{1}{|c|}{$\begin{array}{c}\text { Table 1: Factors of Female Child } \\
\text { Trafficking }\end{array}$} & Agree & Disagree & \multicolumn{1}{|c|}{$\begin{array}{c}\text { Not } \\
\text { sure }\end{array}$} & Total \\
\hline $\begin{array}{l}\text { Female fears due to cultural approval of } \\
\text { honor killing }\end{array}$ & $204(52)$ & $121(30.9)$ & $67(17.1)$ & $392(100)$ \\
\hline $\begin{array}{l}\text { Non-reporting of cases is due to fear of } \\
\text { shame }\end{array}$ & $262(66.8)$ & $103(26.3)$ & $27(6.9)$ & $392(100)$ \\
\hline Gender inequality exists in Pakhtun society & $191(48.7)$ & $120(30.6)$ & $81(20.7)$ & $392(100)$ \\
\hline Pakhtun practices custom of excessive dowry & $204(52)$ & $106(27)$ & $62(20.9)$ & $392(100)$ \\
\hline $\begin{array}{l}\text { Pakhtun disowns sexually abused female } \\
\text { Forced child marriage is culturally approved }\end{array}$ & $215(54.8)$ & $95(24.2)$ & $82(20.9)$ & $392(100)$ \\
\hline $\begin{array}{l}\text { Purchase marriage is culturally approved } \\
\text { Exchange of children (Swara) for disputes } \\
\text { settlement is culturally approved }\end{array}$ & $193(49.2)$ & $103(26.3)$ & $52(13.7)$ & $392(100)$ \\
\hline
\end{tabular}


Values presented in the above table indicate frequency while values in the parenthesis represent percentage Source: Field Survey, 2012

\section{Female Child Trafficking occurs due to}

Table 1 explains the level of agreement of the respondents about the occurrence of child trafficking, where ignorance of parents is reported by more than $78 \%$ of the respondents to be responsible for female child trafficking. Similarly, absence of capable guardian is perceived to be predicting female child trafficking by $76 \%$ of the respondents. It is also agreed by majority of the respondents $(64.8 \%)$ that Pakhtun culture is unable to define child trafficking. Likewise, poor law implementation also paves way for the occurrence of female child trafficking in Pakhtun region. In addition to these cultural influencers, the economic benefits of this business are also indicated by majority $(82.4 \%)$ to be responsible for the crime in the society.

\begin{tabular}{|l|l|l|l|l|}
\hline \multicolumn{1}{|c|}{$\begin{array}{c}\text { Table 2: Female Child Trafficking } \\
\text { occurs due to: }\end{array}$} & \multicolumn{1}{|c|}{ Agree } & Disagree & Not sure & Total \\
\hline Ignorance of parents & $307(78.3)$ & $55(14)$ & $30(7.7)$ & $392(100)$ \\
\hline Absence of capable guardian & $298(76)$ & $49(12.5)$ & $45(11.5)$ & $392(100)$ \\
\hline Unsuited marriage & $188(48)$ & $130(33.2)$ & $74(18.9)$ & $392(100)$ \\
\hline Cultural inability to define CT & $254(64.8)$ & $71(18.1)$ & $67(17.1)$ & $392(100)$ \\
\hline Poor law implementation & $357(91.1)$ & $21(5.4)$ & $14(3.6)$ & $392(100)$ \\
\hline Being profitable business & $323(82.4)$ & $21(5.4)$ & $48(12.2)$ & $392(100)$ \\
\hline
\end{tabular}

\section{Bi and Multivariate Results}

Table 3 and 4 represent bi and multivariate results of the data. The cultural aspect (factors and forms) is positively and significantly associated with child trafficking as evident from the results reported in table 3 .

The negative aspects of Pakhtun culture in the shape of fear among female for losing her life to the so called male/family honor, non-reporting to agencies due to fear of shame, gender discrimination, cultural approval of disowning of abused female, forced child marriage, bride price, Swara marriage are confirmed to be associated with female child trafficking. The findings are in line with the studies of IOM (2004), Trujillo (2004), Chung (2006) and Schauer \& Wheaton (2006), where they claim that non-reporting and gender discrimination in a society provide ample chances to criminals to exploit the situation. 
There is almost no chance for the re-integration and rehabilitation of sexually abused and or blamed to be abused female in Pakhtun culture. She has to face the culturally approved death decorated as "honor killing" by Pakhtun society. This is considered to be the only step of restoration of respect and social status in Pakhtun society. Alternatively, if the abused girl escapes, she might end-up in a broker and trafficker lap. She is not only disowned by her family but also by society at large. Even today, when the country where Pakhtun reside, is run through a democratic modern political constitution and the system is functioning through formal and modern institutions like police, judiciary etc., the Pakhtun continues with the old traditional practices of forced, purchased, and Swara marriages which are not but the forms of extreme exploitation and trafficking. Studies concluded that such exploitative aspects and forms of marriages like Swara, purchased and forced child marriages prevail in Pakistani society (see for example Mirza, 2010; Wolthuis and Blaak, 2001; Banerjee,2003; IOM, 2004; TIP, 2008). Even, in some cases, due to extreme poverty parents sell their daughters (Chung, 2006).

For measuring and ascertaining if this relationship is spurious or non-spurious, a multivariate analysis is carried out which is reported in Table 4. It is observed that the association derived at bivariate level of analysis is non-spurious as envisaged in the multivariate table while keeping gender as controlled variable. Although, there is no major or significant variation in the results with change in gender, however, values of chi square and gamma statistics show that female are more concerned about the prevalence of female child trafficking with reference to the factors and forms referred to in the univariate table in the study area.

Table 3: Association of Cultural Aspect and Female Child Trafficking

\begin{tabular}{l|ll|}
\hline Chi square Value $\chi^{2}$ & Sig & Gamma $(\gamma)$ \\
\cline { 2 - 3 } & .000 & .564 \\
\hline
\end{tabular}

Table 4: Association of Cultural Aspect, Female Child Trafficking and Gender

\begin{tabular}{ll|ll|}
\hline Gender & Chi square Value $\chi^{2}$ & Sig & Gamma $(\gamma)$ \\
\hline \hline Male & 67.672 & .000 & .464 \\
\hline Female & 40.529 & .000 & .874 \\
\hline & & & \\
\hline
\end{tabular}




\section{Conclusions}

Aiming to know about the cultural dimension of female child trafficking in Peshawar, Khyber Pakhtunkhwa, Pakistan, the findings reveal that cultural norms of Pakhtun society play its major role in making environment more open for traffickers to entrap children. Culture is the source of protection; however, in the study area, persistent gender inequality, forced child marriages, purchase marriages, prevalence of excessive dowry, and the customary practice of swara marriage are the factors and forms producing space for criminal syndicate of traffickers to play their dirty game of selling, purchasing, exploiting girls of the region. Due to cultural constraint of shame and insult, families do not report trafficking cases which further motivates offenders. Fear of honor killing is also positively associated with child trafficking. The results remain the same at multivariate level of analysis while keeping gender as controlled variable. It indicates that association of dependent and independent variables is true. The primary results of the study confirm routine activity theory of Cohen and Felson (1979), where negative and inhuman aspect of Pakhtun culture, incapable formal and informal guardian and the motivation of offender interplay and result into female child trafficking. This relationship could be broken by effective awareness raising campaign to identify the existing malpractices in Pakhtun culture. This can be done with the support of civil society organizations working for this cause with the involvement of media, religious and educational institutions. A dialogue is to be initiated at various forums that may bring negative sides of Pakhtun culture to the lime light and suggest necessary remedies for uprooting them. The dark side of the Pakhtun culture is poorly researched and there is a need for further researches to cover the practice of Swara and exchange marriages particularly with a comparative approach of its existence in rural and urban areas, in different tribal societies, in joint and nuclear families, in educated and illiterate families.

\section{Limitations}

No study is complete and without limitations. The present study also has limitations which are provided herewith in such a manner that not only indicate to the limitations but also suggestions for overcoming the same in future studies.

The study has adopted only quantitative methodology which may not have provided in-depth analysis of the issue. It is suggested that future study may be designed to include mix method research approach to fulfill the purpose and overcome the weaknesses of the present study.

The current study only explored association between the variables however, causative relationship is not investigated which requires more advanced techniques, therefore it is 
suggested to explore if these different aspects of Pakhtun culture are causatively associated with child trafficking or only provide a breeding ground to it.

The study is carried out only in Peshawar, it needs to be extended to other parts where Pakhtun resides like tribal areas, Baluchistan, Karachi and even Afghanistan in order to get more broad and holistic picture of the issue, this will also provide further data to compare if there is any difference with reference to areas like tribal belt, rural areas, big city like Karachi.

Another limitation of the study is that it is about female child trafficking however, data is obtained from university teachers, lawyers and journalists which is an indirect approach to explore the issue. It is suggested to include perpetrators, actual families and victims of child trafficking for data collection in a future study.

\section{References}

Afonja, S. (2001).An assessment of trafficking in women and girls in Nigeria Ile Ife., unpublished mimeo.

Ahmad, A. S. (1986). Pakistan Society: Islam, Society and Leadership in South Asia. Oxford Ahmed, N. (1997). Rights-South Asia: Slavery still a thriving trade. Karachi: Inter Press Service.

Ali, S. R. (2013). An Analysis Of Societal Perception On Child Trafficking In Peshawar, Pakistan (Doctoral dissertation, University Of Peshawar, Peshawar).

Ali, S. R., Abdullah, Khan, H. U., \& Karim, W. (2014). Child Trafficking: The Exploitative aspect of Pakhtun Culture. Gomal University Journal of Research, 30(2).

Azam, F. (2009).Report on human trafficking, human smuggling and illegal migration to and from Pakistan: Review of government policies and programmes. Study conducted for BEFARe, Peshawar in Collaboration with Action Aid Pakistan with the support of European Union.

Banerjee, U. (2003). Globalization, crisis in livelihood, migration and trafficking of women and girls: the crisis in India, Nepal and Bangladesh. Un-published paper. Bangladesh Thematic Group on Trafficking.

Child Rights International Network. (2005). Commercial sexual exploitation of children: Tootkit for monitoring and implementing the East Asia and Pacific regional commitment and action plan. Retrieved December 8, 2006, from http://www.crin.org/resources/infoDetail.asp?ID=8472\&flag=report 
Chung, R. C. Y. (2006). Cultural perspective on child trafficking, human rights and social justice: A model for psychologists. Counseling Psychology Quarterly, 22(1), 85-96.

Coalition against Trafficking of Women (CATW), (2003).Trafficking in women and prostitution in the Asia Pacific. Retrieved on September 20, 2011, from http://www.catwinternational.org

Cohen, L. E. \& Felson, M. (1979).Social change and crime rate trends: A routine activity approach. American Sociological Review, (44), 588-608.

Encyclo. (2007). Look-up: Gender inequality. Online encyclopedia retrieved on September 5, from http://www.encyclo.co.uk/local/20212

Iijima, M. (1998).South Asia urged to unite against child prostitution. New York: Reuters.

ILO-IPEC (2002).Annual Report. International Labor Organization, Geneva.

International Labour Organization (ILO) (2006).Demand side of human trafficking in Asia: Empirical findings. Regional Project on Combating Child Trafficking for Labour and Sexual Exploitation (TICSA-II) retrieved on February 22, 2012, fromhttp://www.humantrafficking.org/uploads/publications/ilo06_demand_side_of_h uman_tiaef.pdf

International Labour Organization (ILO). (2002). Unbearable to the human heart: Child trafficking and action to eliminate it. International Programme on the Elimination of Child Labour. International Labour Office, Geneva.

International Organization for Migration (IOM). (2004). Data and research on human trafficking: A global survey. Retrieved on March 19, 2012, from: http://www.google.com/search?hl=en\&ie=ISO-8859 $1 \& q=$ Data+and+research+on+human+trafficking\%3A+A+global+survey+IOM

International Programme on the Elimination of Child Labour- Time Bound Programme (IPEC TBP). (2007). Rapid assessment report in trafficking of children into worst forms of child labour, including child soldiers in Uganda: A study conducted in the districts of Busia, Pader, Kalangala Masaka and Kampala as part of IPEC-TBP Preparatory activities. Retrieved on August 8, 2012, from http://www.ilo.org/ public/english/region/afpro/daressalaam/download/ctrafficking_uganda.pdf

Jeffreys, S. (2009). The industrial vagina: The political economy of the global sex trade. New York: Routledge. 
Kane, J. (1998). Sold for sex, report on the worst forms of child labour. (Compiled by the Global March against child labour). Retrieved on October 5, 2011, from http://www.globalmarch.org

Mirza, M. A. (2010).The Menace of Human Trafficking - Pakistan's Response to the Problem? Pakistan Journal of Criminology 2 (4), 151 - 164.

Morash, M. (2006).Understanding gender, crime, and justice. Thousand Oaks, CA: Sage Publications.

Muhammad, T. (2005). Commercial Sexual Exploitation of Children, A Situation Analysis of Pakistan: Save the Children Sweden Pakistan Programme. Retrieved on August 7, 2012, from http://resourcecentre.savethechildren.se/ commercialsexual-exploitationchildren-situation-analysis-pakistan

Nachmias, D., and Nachmias, C. (1992). Research Methods in Social Sciences. $4^{\text {th }}$ Ed. St Martin's Press Inco. New York. USA.

Noor Education Trust (NET). (2008). Brides for sale: Internal trafficking nexus at a glance. Peshawar. Retrieved on January 15, 2012, from http://netpak.org/ publication.php

Orchard, T. R. (2007). Girl, woman, lover, and mother: Towards a new understanding of child prostitution among young Devadasis in rural Karnataka, India. Soc Sci Med.64 (12), 2379-90.

Papps, I. (1993). Attitudes towards Female Employment in Four Middle Eastern Countries, in Haleh Afshar and Mary Maynard (eds), Women in the Middle East: Perceptions, Realities and Struggles for Liberation, ( pp96-116). London: Macmillan Press.

Raymond, J. G., Hughes, D. M., \& Gomez, C. J. (2010).Sex trafficking of women in the United States. In L. Territo, \& G. Kirkman (Eds.), International sex trafficking of women \& children: Understanding the global epidemic (pp. 3-14). Flushing, NY: Loose leaf Law Publications.

Saewyc, E. M., \& Edinburgh, L. D. (2010). Restoring healthy developmental trajectories for sexually exploited young runaways' girls: Fostering protective factors and reducing risk behaviors. Journal of Adolescent Health, 46, 180-188.

Schauer, E. J. and Wheaton, E. M. (2006). Sex trafficking into the United States: A literature review. Criminal Justice Review.31 (2), 146-169.

Shah, S. (2004). Female Child Trafficking in Swat: From Crime to Custom: SDPI. Retrieved on August 7, 2012, from http://www.sdpi.org/research/ female_child_trafficking.htm

Shah, S. W. A. (2007) North-West Frontier Province: History and Politics. 
Sinha, I. (2005). Trafficking and children at risk. Retrieved on June 12, 2012, from http://www.ashanet.org/focusgroups/sanctuary/articles/sanlaap_trafficking.doc

Trafficking in Children-South Asia (TICSA). (2002). Rapid assessment on trafficking in children for exploitative employment in Bangladesh. Retrieved on January 16, 2012, from http://www.ilo.org/legacy/English/regions/asro/newdelhi/ipec/download/resourc es/subregion/subpubl02eng4.pdf

Trujillo, A. (2004). Slavery in the 21st century. Americas (English Ed.), 56(2), 60-61.

Tumlin, K. C. (2000).Trafficking in children and women: A regional overview. ILO-IPEC paper. Thailand: Institute of Asian Studies.

U.S Department of State, Office to Monitor and Combat Trafficking in Persons. (2008). Trafficking in Persons Report, (TIP) REPORT. University Press Karachi.

Wolthuis, A. and Blaak, M. (2001).Trafficking in children for sexual purposes from Eastern Europe to Western Europe. An exploratory research in eight Western European receiving countries. Ecpat Europe Law Enforcement Group. 